\title{
Impact of Dollarisation on Exchange Rate Volatility and Rational Choice of Currency Regime: Evidence from two EU Candidate Countries $^{4}$
}

\author{
Article history: \\ Received: 11 September 2017 \\ Sent for revision: 28 September 2017 \\ Received in revised form: 31 October 2017 \\ Accepted: 5 November 2017 \\ Available online: 25 December 2017
}

\begin{abstract}
Objective of this paper is to empirically examine whether widespread unofficial dollarisation plays significant role in determination of exchange rate dynamic in Turkey and Serbia, as one big and one small of the EU candidate countries under managed floating currency regime and synthesize consequent policy recommendations. Our time-series approach utilised monthly data from 2006-2016 to research the aforementioned relationship. After resolving non-stationarity issues, we deployed GARCH analysis to pinpoint the sources of volatility. Our research shows that in Serbia dollarisation has significant and robustly positive influence on exchange rate levels, but not so in Turkey, whose national currency is pretty robust in levels yet its volatility is more sensitive than Serbian dinar to volatility of dollarisation. In addition, Serbian foreign exchange reserves share in the money supply positively influences dinar-euro nominal exchange rate volatility, while Turkish reserves' share in money supply has negative impact on exchange rate volatility. Even though uncovered interest parity doesn't hold in either of countries, Serbian dinar is somewhat susceptible to interest rate manipulation, unlike Turkish lira. In the end, one could conclude that flexible exchange rate
\end{abstract}

\footnotetext{
${ }^{1}$ Institute of Economic Sciences, Belgrade, Serbia and University of E. Sarajevo, R. Srpska, BiH marko.malovic@ien.bg.ac.rs

${ }^{2}$ Anadolu University, Eskişehir, Turkey

${ }^{3}$ Institute of Economic Sciences, Belgrade, Serbia

${ }^{4}$ The first and the third author wish to point out that this paper is a part of research projects III47009 and Ol179015, financed by the Serbian Ministry of Education, Science and Technological Development.
} 
Malović M. et al.: Impact of Dollarisation on Exchange Rate Volatility and Rational...

has more sense and better results in Turkey than in Serbia, but rational choice between earlier -agreed upon or unilateral- official dollarisation on the one hand and continuing with managed (systematic) floating on the other in these two EU candidate countries, requires additional, more precise costbenefit analysis, as formalised in the discussion and suggested for future research.

Keywords: dollarisation, exchange rate volatility, currency regime choice, Serbia, Turkey, GARCH

\section{Uticaj dolarizacije na kolebljivost deviznog kursa $i$ racionalan izbor deviznog režima: rezultati iz dve zemlje- kandidatkinje za EU}

Apstrakt: Cilj ovog rada je da empirijski ispita da li rasprostranjena nezvanična dolarizacija igra statistički značajnu ulogu u determinaciji dinamike deviznog kursa u Turskoj i Srbiji, kao jednoj velikoj i jednoj maloj kandidatkinji za ulazak u EU, u oba slučaja u režimu rukovođeno plivajajućeg kursa, te da sintetiše preporuke kreatorima ekonomske politike. Naša analiza vremenskih serija koristi mesečne podatke u rasponu 2006-2016 za izučavanje pomenutog uticaja. Nakon rešavanja problema nestacionarnosti u serijama, primenili smo GARCH metodologiju kako bismo izolovali izvore kolebljivosti kurseva. Naše istraživanje pokazuje da u Srbiji dolarizacija ima značajan i robusno pozitivan uticaj na nivo deviznog kursa,ali ne $i$ u Turskoj,čija je valuta prilično otporna na stepen dolarizacije u nivou, ali čije su oscilacije osetljivije na kolebljivost intenziteta dolarizacije nego promene kursa dinara. Nadalje, udeo deviznih rezervi Srbije u monetarnoj masi pozitivno utiče na kolebljivost nominalnog kursa dinar-evro, dok udeo turskih deviznih rezervi u monetarnoj masi ima negativan uticaj na kolebljivost deviznog kursa lire. lako nepokriveni kamatni paritet nije ispunjen ni u jednoj od dve zemlje, dinar je nešto podložniji manipulacijama kamatnom stopom za razliku od turske lire. Na kraju, mogli bismo zaključiti da plivajući devizni kurs ima više smisla i daje bolje rezultate u Turskoj nego u Srbiji,ali racionalni izbor između ranije -prećutno dogovorene ili unilateralne- oficijelne dolarizacije na jednoj ili nastavka sa rukovođenim (pragmatičnim) plivanjem na drugoj strani u ove dve zemlje-kandidatkinje za članstvo u EU,iziskuje precizniju analizu troškova $i$ koristi, što smo $i$ formalizovali u zaključku $i$ apostrofiramo kao predmet budućeg istraživanja.

Ključne reči: dolarizacija, kolebljivost deviznog kursa, izbor režima deviznog kursa, Srbija, Turska, GARCH. 
Malović M. et al.: Impact of Dollarisation on Exchange Rate Volatility and Rational...

\section{Introduction}

Increasingly widespread use of foreign currency deposits and cash in better part of the world has no doubt complicated exchange rate- and monetary policymaking. Besides, poetic irony is that while dollarisation phenomenon was driven by firms' and households' desire to insulate themselves from inflation and currency risk, it may have baloonned the systemic risk in both national and international scope [Honohan, 2007, p.22].

The effectiveness of monetary and exchange rate policy in highly dollarised small open economies is the subject of an ongoing discussion, since growing body of research suggests that in a more heavily dollarised economy monetary policy seems to be less effective, more sluggish in terms of impact and by all means more complex. In fact, there are convincing theoretical arguments, which imply that dollarisation tends to increase volatility of floating exchange rate. For instance, Reinhart, Rogoff and Savastano (2003), as well as Alvarez-Plata and Gracia-Herrero (2007) warn against sensitive interplay between exchange rate and monetary policy designed in de facto two money terms. In addition, Berg and Borensztein (2000) claim that interaction between money supply and exchange rate is the main transmission channel through which currency substitution affects exchange rate volatility, implying that high elasticity of substitution between domestic and foreign currency will trigger exchange rate instability in case of money supply changes; Direct recommendation of such argumentation being that anchoring of the exchange rate rather than inflation may be better solution in a highly dollarised small open economy. After all, Malovic (2007) argued that in inflation targeting monetary regimes of transition economies exchange rate must also be targeted with much less flexibility than theoretically preached. Benkovskis and Wörz (2014) as well as Di Mauro, Benkovskis, De Pinto and Grazioli (2016) uncover, while Blanchard (2016) himself admits, as a matter of fact, rather limited role for exchange rate manipulation in achieving export competitiveness and ultimately market share.

Hence, the aim of this paper is to empirically verify the extent to which heavy dollarisation intensifies flexible exchange rate instability in one super small and one larger EU candidate country, namely Serbia and Turkey, in an attempt to reconsider the rational choice of a currency regime in these and similar economies. In other words, we have tried to tentatively answer the dilemma whether highly dollarised small open economies with large degree of de-industrialisation under way still have non-trivial benefits of flexible exchange rate regime to reap, or indeed official dollarisation (unilateral if not tacitly agreed upon) offers itself as an optimal alternative, ceteris paribus. The rest of the paper is organised as follows. In section 2, we review the theoretical background of the problem with particular focus on impact of 
Malović M. et al.: Impact of Dollarisation on Exchange Rate Volatility and Rational...

dollarisation on exchange rate volatility and effectiveness of managed floating regime in Serbia and Turkey. In section 3, we lay down the chosen methodology and carry out empirical research. In section 4, we lay down empirical results and provide short discussion both in terms of contrasting them with other people's work and sketching alleys for future research. Finally, in section 5, we draw the main policy relevant conclusions and recommendations.

\section{Theoretical Background}

During the process of negotiation with the EU, once admitted in the Union, today's candidate countries will consider when to start qualifying in an attempt to become members of the EMU, which basically means full and coordinated (mutually agreed upon) dollarisation and giving up the independency of monetary policy as well as exchange rate, which are otherwise and traditionally regarded as rather useful instruments of macroeconomic adjustment. This decision will be particularly important for the countries (Turkey, Serbia) that adopted flexible inflation targeting as the monetary policy framework and more or less floating exchange arrangement. Since all of these economies are dollarised to a considerable extent, proposed empirical analysis will provide valuable evidence on whether currency substitution really exhibits detrimental effects on exchange rate volatility, and consequently, whether the potential admission to the EMU or unilateral dollarisation even (at a loss of whatever monetary independence these countries de facto retained thus far) may hypothetically still be beneficial from the standpoint of increased exchange rate stability. Or in other words, it may provide evidence whether de-dollarisation in these countries could in fact be beneficial in case that they decide not to change, but to strengthen existing monetary policy framework within certain package of necessary structural reforms.

A term dollarisation, by and large, denotes phenomenon of (un)officially adopting foreign currency as a legal tender in parallel or instead of domestic money. It can stand for deposit/loan dollarisation, circulating currency substitution or be a consequence of assets portfolio optimisation. De facto or unofficial dollarisation is often called and confused with currency substitution, since according to Calvo and Vegh (1996) dollarisation should be used only for utilising foreign money as a measure and store of value, while usage of foreign money in everyday transactions ought to be differentiated as currency substitution. Be that as it may, non-negligible dollarisation phenomenon in mid to long run, when uncovered interest rate parity is supposed to hold, always boils down to optimizing financial portfolio in terms of minimisation of losses stemming from dynamic relationship between volatility of expected revenues (approximated by exchange rate pattern) and inflation (i.e. nominal interest 
Malović M. et al.: Impact of Dollarisation on Exchange Rate Volatility and Rational...

rate) volatility for every FX segment on the balance sheet [Chailloux\&Ohnsorge\&Vavra, 2010], [Rajkovic\&Urosevic, 2014].

It is often argued that in a highly dollarised economy monetary policy loses much of ist ability to anchor nominal variables [Vegh, 2013], whereas activist exchange rate policy itself becomes a double-edged sword in that while repairing export-price competitiveness worsens a body of FX denominated debt transactions within national economy as well. Unofficial dollarisation originates from a lack of faith in domestic currency. Moreover, when a country at hand i.e. its GDP is heavily import dependant, then impact of real exchange rate on imports and exports becomes somewhat less predictable. In the case of Serbia, it appears that insufficiently competitive national currency (not high enough nominal exchange rate) serves as a proverbial and eternal excuse for all other deficiencies of Serbian export supply. Malovic (2015), for instance, therefore maintains that Serbia has probably foregone all the textbook benefits of managed float, due to the absence or ambiguity of overall development, industrial and export promotion policies, in that there is no grown up and qualitatively mature enough production potential which would much like a sail- catch the wind provided by managed (real) depreciation of national currency. On the other hand, Civcir (2003) in the case of Turkey, also finds interest rate (inflation) differential and (un)expected but unfavourable exchange rate movements to be the dominant variables in determining dollarisation extent. However, Turkey is characterised by another peculiarity: much of its imports are denominated in euros, whereas slightly larger chunk of ist exports is denominated in US dollars.

Regardless of the details, it is always a doubt that government will carry proper long term stable currency policy that drives an escape into dollarisation. However, recent empirical results indicate that improved government quality does indeed reduce unofficial dollarisation, but exchange rate regime plays no direct role in either promoting or curing dollarisation trend [Honig, 2007], [Berkmen\&Cavallo, 2009]. Nevertheless, Honohan (2007) as well as Mwase and Kumah (2015) rightly observe that in spite of private demand for foreign currency may well remain unaltered in FX terms, there could be large fluctuations in the effective extent of dollarisation precisely because of too volatile floating exchange rate movements. Thus, apart from short term indirect reverse causality effect, thanks to which exchange rate $s$ feature as determinants of financial dollarisation in related literature, there is actually no sustainable longer-term impact of exchange rate regimes on the severity of dollarisation, which is not to say that a priori presence of widespread dollarisation doesn't have a bearing on the volatility of floating exchange rate or indeed on post-festum rational choice of exchange rate regime. Hence, for starters, we decided to econometrically investigate the significance of dollarisation's impact of exchange rate volatility. 
Malović M. et al.: Impact of Dollarisation on Exchange Rate Volatility and Rational...

\section{Methodology and Data}

Empirical strategy is inspired by the work of Lay,Kakinaka and Kotani (2012). Basically, it applies GARCH methodology to assess whether and to which extent level of dollarisation affects level and volatility of the nominal exchange rate. As usual in case of $\mathrm{GARCH}$ approach, exchange rate is modeled by mean and variance equations, where:

mean equation models change in nominal exchange rate (in logarithmic terms) $\Delta\left(L_{-} F X\right)_{t}$, since its first differences are stationary, as a dependent variable, against its lags up to order $p$, change in total dollarisation index $\Delta(T D I)_{t}$ being main explanatory variable and other control variables $X_{t, j}$ on the RHS of the equation:

$\Delta\left(L_{-} F X\right)_{t}=a_{0}+\sum_{i=1}^{p} a_{i} \Delta\left(L_{-} F X\right)_{t-i}+b \Delta(T D I)_{t}+\sum_{j=1}^{k} c_{j} X_{t, j}+\epsilon_{t}$

$\epsilon_{t}=\sigma_{t} \varepsilon_{t}, \quad \varepsilon_{t} \sim N(0,1)$;

variance equation models conditional variance of changes in exchange rate against news about volatility (ARCH terms) and forecasted variances (GARCH terms) up to $q$ and $m$ previous periods), dollarisation index and other control variables on the RHS of the equation.

$\epsilon_{t}^{2}=\omega+\sum_{i=1}^{q} \alpha_{i} \epsilon_{t-i}^{2}+\sum_{j=1}^{m} \beta_{j} \sigma_{t-j}^{2}+\gamma \Delta(T D I)_{t}+\sum_{j=1}^{k} \delta_{j} X_{t, j}$

Estimation of the model requires the following dataset (monthly-based):

- Nominal exchange rate of domestic currency (against currency of benchmarking economy, basically against euro and in the case of Turkey also against US dollar)

- $\quad$ Broad money (M2)

- $\quad$ Foreign exchange reserves (total)

- Foreign currency deposits (total)

- CPIs of both national and benchmarking economies

- Interest rates applicable on bank deposits of both national and benchmarking economies

Based on these time series, the following variables for all countries are computed:

- $\quad$ Change in nominal exchange rate (in logarithmic terms)

- Dollarisation index as a ratio of foreign currency deposit and M2 (measure of dollarisation)

- $\quad$ Foreign exchange reserve to M2 (control variable), RES_M2

- Real interest rate difference between national and benchmark economy (control variable), RID. 
Malović M. et al.: Impact of Dollarisation on Exchange Rate Volatility and Rational...

Choice of lag length in mean and variance equation is primarily based on Swarz information criterion, but we also took into account explanatory power of the model. These criteria combined suggest choice of $\operatorname{AR}(3) \operatorname{GARCH}(1,1)$ and $\operatorname{AR}(2) \operatorname{GARCH}(1,1)$ as the most suitable empirical specifications in case of Serbia and Turkey, respectively. Robustness check is based on the estimation of alternative GARCH specification as Exponential GARCH and Component GARCH.

\section{Empirical Results and Discussion}

Our empirical analysis covers the period 2006M1-2016M3. Basic characteristics of the model variables in the observed period are provided in the Table 1.

Table 1. Descriptive Statistics

$\begin{array}{cccccc}\text { Serbia } & \text { Mean } & \text { Median } & \text { Maximum } & \text { Minimum } & \text { Std. Dev. } \\ \text { L_FX } & 4.61 & 4.64 & 4.82 & 4.34 & 0.15 \\ \bar{T} D I & 65.67 & 67.17 & 72.41 & 56.03 & 4.54 \\ R E S M 2 & 88.70 & 85.33 & 131.89 & 69.03 & 12.66 \\ \text { RID } & 1.63 & 1.93 & 7.13 & -7.39 & 3.27 \\ \text { Turkey } & \text { Mean } & \text { Median } & \text { Maximum } & \text { Minimum } & \text { Std. Dev. } \\ \text { L_FX } & 0.81 & 0.79 & 1.22 & 0.46 & 0.19 \\ \bar{T} D I & 35.01 & 34.61 & 46.37 & 26.15 & 3.99 \\ R E S M 2 & 14.98 & 14.11 & 23.97 & 7.70 & 4.27 \\ R I D & 0.80 & 0.98 & 2.00 & -0.74 & 0.72\end{array}$

Source: Author's calculation

Data for Serbia show that level of dollarisation was stable and never dropped below $50 \%$. Opposite, share of foreign reserves and especially real interest rate differentials exhibit high volatility within the large range of variations.

Before model estimation, we test the presence of the unit roots in the time series in the standard manner, using augmented Dickey-Fuller (ADF) test. Both options including only intercept and trend with intercept are considered. Results of unit root tests are presented in Table 2. The results of ADF test indicate that all variables used in the study are first difference stationary variables. Thus, we use the logarithmic first differences of exchange rates as a dependent variable to estimate the mean exchange rate equation in order to avoid detrimental effects of non-stationarity on reliability of estimations. 
Malović M. et al.: Impact of Dollarisation on Exchange Rate Volatility and Rational...

Table 2. ADF Unit Root Tests

$\begin{array}{lllll} & \text { Serbia } & & \text { Turkey } \\ \text { Level } & \text { Intercept } & \text { Trend } & \text { Intercept } & \text { Trend } \\ \text { L_FX } & -0.532774 & -2.808874 & -0.941609 & -2.699610 \\ \text { TDI } & -1.234156 & -0.819003 & -1.030733 & -1.420686 \\ \text { RES_M2 } & -1.300406 & -2.550643 & -0.775669 & -2.022167 \\ \text { RID } & -3.028437^{* *} & -2.939989 & -2.039605 & -2.490447 \\ \text { Difference } & \text { Intercept } & \text { Trend } & \text { Intercept } & \text { Trend } \\ \text { L_FX } & -12.02632^{* * *} & -11.99708^{* * *} & -8.767427^{* * *} & -8.727976^{* * *} \\ \text { TDI } & -17.03507^{* * *} & -17.04908^{* * *} & -3.449953^{* * *} & -6.876954^{* * *} \\ \text { RES_M2 } & -13.51687^{* * *} & -13.46155^{* * *} & -3.470706^{* * *} & -3.451293^{* * *} \\ \text { RID } & -8.961096^{* * *} & -8.988922^{* * *} & -3.344563^{* * *} & -3.330511^{* * *}\end{array}$

Source: Author's calculation

Finally, we estimate the relevant $\operatorname{AR}(p) \operatorname{GARCH}(q, p)$ models for Serbia and Turkey. The results of the estimation are presented in Table 3. Sum of ARCH and GARCH regression coefficients in both cases are considerably less than 1 , so we dismiss integrated GARCH as an alternative model specification. In addition, we estimate alternative EGARCH and $\mathrm{C}-\mathrm{GARCH}$ versions of the baseline specification, which estimates mostly coincide with baseline.

Table 3. GARCH estimates

\begin{tabular}{|c|c|c|c|c|}
\hline \multirow[b]{2}{*}{ Mean Equation } & \multicolumn{2}{|c|}{ Serbia AR(3) GARCH(1.1) } & \multicolumn{2}{|c|}{ Turkev AR(2) GARCH(1.1) } \\
\hline & Coeff & $\mathrm{p}$-value & & \\
\hline$C$ & 0.003791 & 0.0789 & 0.006768 & 0.7002 \\
\hline$D\left(L_{-} T D I\right)$ & $0.439638^{* * *}$ & 0 & 0.067666 & 0.4746 \\
\hline$D\left(R E S \_M 2\right)$ & 0.000856 & 0.1768 & $-0.230972^{* * *}$ & 0.0067 \\
\hline$D(R I D)$ & -0.001859 & 0.1265 & 0.000104 & 0.9203 \\
\hline$A R(1)$ & -0.081666 & 0.385 & $0.195202^{*}$ & 0.0641 \\
\hline$A R(2)$ & 0.047747 & 0.6436 & $-0.304899^{* \star *}$ & 0.0017 \\
\hline$A R(3)$ & $0.276052^{* * *}$ & 0 & & \\
\hline Variance equation & Coeff & $\mathrm{p}$-value & Coeff & $\mathrm{p}$-value \\
\hline$C$ & 0.000159 & 0.0006 & 0.000544 & 0.2676 \\
\hline$R E S I D(-1)^{\wedge} 2$ & $0.63651^{* *}$ & 0.0101 & 0.017543 & 0.7823 \\
\hline $\mathrm{GARCH}(-1)$ & 0.141023 & 0.3592 & $0.558955^{\star}$ & 0.0611 \\
\hline$D\left(L_{-} T D I\right)$ & -0.00109 & 0.6752 & $0.005009^{*}$ & 0.0906 \\
\hline$D\left(R E S \_M 2\right)$ & $2.80 \mathrm{E}-05^{\star \star \star}$ & 0.0091 & $-0.006104^{\star \star *}$ & 0.0009 \\
\hline$D(R I D)$ & $-6.21 \mathrm{E}-05^{\star * *}$ & 0.0048 & $-1.08 \mathrm{E}-05$ & 0.6926 \\
\hline
\end{tabular}

Note: Level of significance: ${ }^{* * *}$ if $p<0.01,{ }^{* *}$ if $p<0.5,{ }^{*}$ if $p<0.1$

Source: Author's calculation 
Malović M. et al.: Impact of Dollarisation on Exchange Rate Volatility and Rational...

Our empirical results are therefore somewhat mixed for the selected two countries, but also rather interesting and to that extent bear implicit policy relevance.

I) Dollarisation index in Serbia exhibits robustly positive influence on nominal exchange rate dynamics; hence in levels this seems to be the most indisputable finding of the entire estimation! In other words, the larger the level of euroisation of the Serbian economy, the bigger depreciation of dinar one might safely expect. However, dollarisation index in Turkey doesn't exert statistically significant influence on nominal exchange rate dynamics. This is so arguably because of unique almost complete separation of the Turkish financial subsystems simultaneously operating in lira, dollar and euro.

II) Nonetheless, change in Serbian dollarisation index doesn't exert influence on monthly volatility of dinar-euro exchange rate. Hence, Serbian dollarisation problem seems to be chronic rather than acute, in a sense that miniscule alterations of otherwise huge dollarisation index don't seem to rub on the exchange rate much. In Turkey, however, there's a positive statistically significant impact of dollarisation index's movements on volatility of nominal exchange rate as theoretically expected, considering the fact that Turkey has almost textbook example of dual money system with widespread independent use of both dollar and euro as transaction media, store of value and units of account.

III) FX reserves' share in Serbian money supply doesn't have influence over exchange rate (some of them served a window-dressing purpose anyway), but positively influences dinar-euro nominal exchange rate volatility (seasonal effects, holidays vacations either bring the FX in with Gastarbeiter and tourists, or cause dual currency portfolio adjustment as people exchange euros to pay for traditional seaside vacations, property or dearer consumer goods). In Turkey, FX reserves share in money supply exhibits negative impact on nominal exchange rate, because the level of reserves has been apparently playing the key role all along, like an anchor, to determine the value of TRY against the dollar. Additionally, the Turkish reserves' share in money supply has negative impact on exchange rate volatility, in other words this implies that more volatility of official reserve holdings goes hand in hand with lower levels of exchange rate (deploying FX reserves enables exchange rate to stay put or move less extremely).

IV) Real interest rate differential (we are talking about domestic and foreign real interest rates on FX deposits) doesn't show systemic impact on exchange rate (uncovered interest parity apparently and expectedly doesn't hold) neither in Serbia nor in Turkey, but once again real interest rate differential negatively influences nominal exchange rate volatility in Serbia, since more frequent manipulation with domestic interest rate strengthens domestic currency via some sort of Clarida-Waldman effect, i.e. by demonstrating central bank's 
Malović M. et al.: Impact of Dollarisation on Exchange Rate Volatility and Rational...

determination to correct and rectify FX market developments (which in turn lowers exchange rate volatility). For Turkey, in terms of variance equation, no significant relationship has been found.

This might further mean that flexible exchange rate is more sustainably integrated in Turkish economy and has more sense in the country with big real productive export oriented sector, than in small highly indebted open economy with tiny industrial capacities. However, we sadly cannot categorically claim the result described, since we didn't control for de facto flexibility (or lack thereof) of either managed floating exchange rate regime in those two countries, along the lines of Frankel (2017), for example. Nonetheless, our result remains very much in spirit of Edwards' (2015) finding that for small open economies with flexible exchange rates, inflation targeting framework and capital mobility, monetary policy independence is in fact largely an illusion, due to policy contagion from- and lock-step relationship with- the activity of central bank whose currency is embraced by de facto dollarisation (Fed and ECB).

Be that as it may, even though uncovered interest parity doesn't hold in either of countries during period under consideration, analysis carried out in this paper also demonstrates that Serbian dinar appears susceptible to interest rate manipulation much akin to Clarida-Waldman mechanism (when bad news on inflation imply good news for exchange rate because of central bank credibility and mean reverting market expectations), unlike Turkish lira, where no significant relationship between interest rate differential and nominal exchange rate volatility has been found. As recently illustrated by Malovic (2015, p.162), Samsen (2015, p.3) and Malovic et alia (2017, p.13), despite comprehensive de-dollarisation strategies of their respective central banks, degrees of dollarisation in either Serbian or Cambodian economy have not dramatically decreased, perhaps precisely because of the interest rate policy [Honohan, 2007, p.22].

However, notwithstanding the importance of nominal exchange rates for relaxing or tightening the foreign (currency denominated) debt noose, for macroeconomic adjustment in international setting much more weight is attached to real exchange rate. The trouble is, in highly dollarised economies whose industries heavily rely on imports, the impact of dollarisation on real exchange rate and current account often times becomes less clear and more ambiguous, pending on the type of shocks driving developments (domestic or external, real or financial).

Furthermore, the fact that dollarisation in Serbia exerts significant and disruptive influence on floating exchange rate regime, does not automatically imply that official dollarisation would be superior, just the same as the fact of floating Turkish lira still making economic sense in spite of many challenges of dual foreign currency presence does not eo ipso imply that the float is 
Malović M. et al.: Impact of Dollarisation on Exchange Rate Volatility and Rational...

superior to any other exchange rate regime, including official dollarisation to either euro or greenback.

Therefore, in order to be able to reach a lege artis decision and rationally embrace strategies for even more forceful promotion of domestic currency or to abandon the float in favour of official dollarisation, one would ideally have to attempt to calibrate the costs and benefits of the alternatives. For instance, value at risk methodology used to that end, under the managed floating could be proxied as:

$$
V a R^{\text {float }}=-\alpha \Delta R^{\$}+\psi \Delta D_{\Delta \varepsilon}-\theta \Delta B
$$

Well managed floating exchange rate could arguably save some of the FX reserves $R^{\$}$ which would otherwise be spent on defending a given parity, or via competitive terms of trade might even earn some, all of which decreases the value at risk. The portion of country's debt $D_{\Delta \varepsilon}$ which rises due to unfavourable exchange rate movements increases the value at risk, while balance of payments effect may go either way. Greeks are obviously the weights that would have to be estimated for each economy.

Similarly, value at risk under official unilateral dollarisation ${ }^{5}$ as a currency regime, on a top of current account balance and foreign exchange reserves already introduced in equation (3), would have to be concerned with the loss of seignorage too:

$$
V a R^{\epsilon}=-\xi \Delta R^{\Phi}+\zeta h \pi /(1+\pi)-\eta \Delta B
$$

Seignorage forgone is formalised by the multiplication of the real (deflationarised) value of high-powered money $h$ and a fraction driven by inflation rate $\pi$ in the second term of equation (4). Sure enough, one would encounter fair many difficulties in obtaining the data for this excercise, let alone in employing several control variables to discern other independent development which might affect our key variables in the counterfactual alternative, which is why we left it for the time being as an avenue for future research.

\section{Concluding Remarks}

Our empirical analysis has showed that dollarisation's impact on exchange rate level is much more pronounced in Serbia than in Turkey. Turkish lira

\footnotetext{
${ }^{5}$ Obviously, mutually agreed official dollarisation would provide additional benefit of participation in the seignorage of the currency newly adopted.
} 
Malović M. et al.: Impact of Dollarisation on Exchange Rate Volatility and Rational...

appears to be pretty robust to dollarisation extent in levels, yet it's volatility is more sensitive than Serbian dinar to dollarisation index. In addition, results indicate that dinar-euro exchange rate is much more vulnerable to change in FX reserves share in the money supply than Turkish lira nominal exchange rate.

Even though uncovered interest parity doesn't hold in either of countries, Serbian dinar is somewhat susceptible to interest rate manipulation, unlike Turkish lira. In the end, one could conclude that flexible exchange rate has more sense and better results in Turkey than in Serbia, but rational choice between earlier -agreed upon or unilateral- official dollarisation on the one hand and continuing with managed (systematic) floating on the other in these two EU candidate countries, requires additional, more precise cost-benefit analysis, as formalised in the discussion and suggested for future research.

\section{References}

Alvarez-Plata, P. \& Garcia-Herrero, A. (2007), "To dollarize or de-dollarize: Consequences for Monetary Policy", paper prepared for the Asean Development Bank, mimeo.

Benkovskih, K. \& Wörz, J. (2014), "What drives the Market Share Changes? Price versus Non-Price Factors", ECB Working Paper \#1640, Frankfurt am Main.

Berg, A. \& Borensztein, E. (2000), "The Choice of Exchange Rate Regime and Monetary Target in highly dollarized Economies", Journal of Applied Economics, Vol. 3, pp. 285-324.

Berkmen, S. P. \& Cavallo, E. A. (2009), "Exchange Rate Policy and Liability Dollarization: What do the Data reveal about Causality?", IMF Working Paper \#07/33, International Monetary Fund, Washington, DC, June.

Blanchard, O. (2016), "Currency Wars, Coordination and Capital Controls", Peterson Institute for International Economics, May $6^{\text {th }}$, mimeo.

Calvo, G. \& Vegh, C. (1996), "From Currency Substitution to Dollarization and Beyond: Analitical and Policy Issues", in Calvo, G. (ed.) Money, Exchange Rates and Output, The MIT Press, Cambridge, MA, pp. 153-175.

Civcir, I. (2003), "Dollarization and its Long Run Determinants in Turkey", Middle East Economies series, forthcoming, mimeo.

Chailloux, A., Ohnsorge, F. \& Vavra, D. (2010), "Euroisation in Serbia”, EBRD Working Paper No. 120, London, October.

Di Mauro, F., Benkovskis, K., De Pinto, S. \& Grazioli, M. (2016), „Fighting Currency Wars with Blanks: The Limited Role of Exchange Rates in Export Competitiveness", Vox CEPR Policy Portal, June $29^{\text {th }}$, mimeo.

Edwards, S. (2015), "Monetary Policy Independence under Flexible Exchange Rates: An Illusion?", NBER Working Paper \#20893, Cambridge, MA, January.

Frankel, J. (2017), "Systematic Managed Floating", NBER Working Paper \#23663, Cambridge, MA, August.

Honig, A. (2007), "Dollarization, Exchange Rate Regimes and Government Quality", Department of Economics, Amherst College, Amherst, MA, mimeo. 
Malović M. et al.: Impact of Dollarisation on Exchange Rate Volatility and Rational...

Honohan, P. (2007), "Dollarization and Exchange Rate Fluctuations", WB Policy Research Working Paper \#4172, World Bank, Washington, DC, March.

Lay, S., Kakinaka, M. \& Kotani, K. (2012), "Exchange Rate Movements in a dollarized Economy: The Case of Cambodia” ASEAN Economic Bulletin Vol. 29(1), pp. 6578 .

Malovic, M. (2007), "Exchange Rate Regimes and Monetary Policies in Emerging Markets: A Showdown for Few Theoretical Misconceptions", CsGG Discussion Paper 42 (monograph), London School of Economics, London.

Malovic, M. (2015), "Has the Time come for Official Dollarisation in Serbia?", in I. Stosic, M. Malovic and D. Filimonovic (eds) Structural Adjustment in Serbia thusfar achieved results and prognosis, Institute of Economic Sciences, Belgrade (in Serbian).

Malovic, M., Zdravkovic, A., Bodroza, D. \& Stosic, I. (2017), "Analiza makroekonomskih pokazatelja”, Institute of Economic Sciences\&NBS, Belgrade, April, mimeo.

Mwase, N. \& Kumah, F. (2015), "Revisiting the Concept of Dollarization: The Global Financial Crisis and Dollarization in Low-Income Countries", IMF Working Paper \#12, International Monetary Fund, Washington, DC, January.

Rajkovic, I. \& Urosevic, B. (2014), "Dollarization of Deposits in the Short- and LongRun: Evidence from CESE Countries", NBS Working Paper \#28, Belgrade, December.

Reinhart, C., Rogoff, K. \& Savastano M. (2003), "Addicted to Dollars”, NBER Working Paper \#10015, Cambridge, MA.

Samsen, N. (2015), "Promote Riel and De-Dollarization through Exchange Rate Policy: Fix or Float or Anything else?", paper presented at the conference Leveraging Financial Markets to promote the Use of Riel, National Bank of Cambodia, September, mimeo.

Vegh, C. (2013), "Open Economy Macroeconomics in Developing Countries", The MIT Press, Cambridge, MA. 